Kumawula, Vol. 3, No.3, Desember 2020, Hal 457 - 464 DOI: https://doi.org/10.24198/kumawula.v3i3.28348

ISSN 2620-844X (online)

Tersedia online di http://jurnal.unpad.ac.id/kumawula/index

\title{
DINAMIKA LEMBAGA PELAYANAN SOSIAL DALAM MEMBERIKAN LAYANAN DI TENGAH PANDEMI
}

\author{
Gina Sonia ${ }^{*}$, Rudi Saprudin Darwis ${ }^{2}$ \\ ${ }^{1}$ Mahasiswa Program Studi Sarjana (S-1), Ilmu Kesejahteraan Sosial Fakultas Ilmu Sosial dan Ilmu Politik, \\ Universitas Padjadjaran \\ ${ }^{2}$ Dosen Program Studi Kesejahteraan Sosial, Fakultas Ilmu Sosial dan Ilmu Politik, Universitas Padjadjaran
}

*Korespondensi : gina17005@mail.unpad.ac.id

\begin{abstract}
ABSTRAK
Pandemi menyebabkan perubahan dalam berbagai aspek kehidupan. Salah satunya adalah dalam cara berinteraksi dengan orang lain. Meskipun dalam situasi pandemi, pelayanan yang dilakukan oleh organisasi sosial harus tetap dilakukan mengingat situasi pandemi berdampak pada kelompok-kelompok rentan seperti andik-andik di LPKA dan remaja-remaja marjinal. Penelitian ini merupakan penelitian tindakan atau Action Research yang dilakukan melalui pengkajian suatu permasalahan atau fenomena dalam ruang lingkup yang terbatas. Penelitian ini dilaksanakan di Kota Bandung, Jawa Barat dengan subjek penelitian Mitra Citra Remaja (MCR). Pengkajian ini dilakukan dalam konteks pengorganisasian (organizing) berbagai elemen yang ada di dalam satu struktur kerelawanan dalam rangka penggalangan dana dan kampanye sosial. Rekomendasi yang ditawarkan adalah lembaga mempersiapkan dan mengawali program layanan dengan melakukan penelitian, merancang program sesuai dengan hasil penelitian, membuat kontak terpadu dalam semua kegiatan dan mengoptimalkan media masa menjadi media arus utama pelaksanaan program layanan.
\end{abstract}

Kata kunci: pandemi, pelayanan sosial, pengorganisasian

\begin{abstract}
A pandemic causes changes in various aspects of life, including how to interact with other people. Even in a pandemic, services provided by social organizations must still be carried out considering that the pandemic situation also affects vulnerable groups such as proteges in LPKA and marginalized youth. This research is an Action Research that was carried out through the study of a problem or phenomenon in a limited scope. This research was conducted in Bandung, West Java, with the research subject of Mitra Citra Youth (MCR). This study was carried out in the context of organizing the various elements in a voluntary structure in the context of fundraising and social campaigns. The recommendations offered to preparing and initiating service programs by conducting research, designing programs according to the results of research, making integrated contacts in all activities and optimizing mass media to become the mainstream media in implementing service programs.
\end{abstract}

Keywords: pandemic, social service, organizing

\section{PENDAHULUAN}

Dewasa ini, eksistensi lembaga pelayanan sosial mulai diakui. Bukan tanpa alasan, lembaga pelayanan sosial mampu membantu masyarakat dengan menyediakan layanan yang tidak disediakan oleh pemerintah. Lembaga pelayanan sosial memiliki fungsi utama menyelenggarakan pelayanan kesejahteraan sosial yang ditujukan untuk memecahkan masalah dan atau memenuhi kebutuhan masyarakat Hal ini menjadikan lembaga-lembaga atau organisasi-organisasi non pemerintah (NGO) sebagai sebuah lembaga yang dapat membantu mengatasi masalah sosial yang terjadi dalam masyarakat.

Tidak hanya membantu mengatasi masalah saja, lembaga-lembaga non pemerintah pun dapat bergerak pada ranah pemberdayaan atau pengembagan masyarakat dalam rangka memenuhi kebutuhan masyarakat. Hal ini tentu 
saja menjadi nilai tambah di mana lembagalembaga pemerintah dapat bersinergi dengan lembaga-lembaga non pemerintah dalam mengatasi masalah sosial dan memberdayakan masyarakat sehingga upaya-upaya mewujudkan kesejahteraan masyarakat dapat lebih mudah direalisasikan sehingga masyarakat dapat berdaya dan melaksakan fungsi sosialnya.

Akan tetapi, jika hanya lembagalembaga sosial yang bergerak dan tidak ada dukungan dari masyarakat itu sendiri, kesejahteraan masyarakat akan sulit diwujudkan. Belum lagi adanya faktor penghambat yang lain, seperti penerimaan masyarakat terhadap pelayanan sosial, kemudahan akses terhadap pelayanan sosial, dan ketersediaan sumber untuk menjangkau pelayanan sosial pun menjadi tantangan tersendiri dalam melaksanakan upaya-upaya pelayanan sosial. Hal ini membuat pelayanan sosial menjadi aktivitas yang memerlukan koordinasi yang baik dan holistik.

Kendati demikian, tetap saja masalah sosial bukan hal yang mudah untuk dipecahkan. Dalam pengertian sehari-hari, masalah adalah suatu hambatan yang dialami dan membutuhkan pemecahan dengan cara yang benar dan tepat (Tangdilintin, 2015). Singkatnya masalah sosial adalah ketidaksesuaian antara kondisi yang diharapkan dengan kenyataan yang sebenarnya terjadi sehingga timbulah kesenjangan sosial. Dengan kata lain, masalah sosial merupakan permasalahan multidimensional di mana permasalahan yang satu dapat menyebabkan atau disebabkan oleh permasalahan yang lain yang merugikan banyak pihak.

Kekinian, permasalahan pandemi menjadi masalah sosial. Hal ini karena awalnya, pandemi merupakan masalah kesehatan akan tetapi semakin lama permasalahan ini bergeser menjadi masalah sosial saat dampak dari pandemi ini menimbulkan kesengsaraan dalam skala global. Pandemi ini juga menimbulkan kesenjangan sosial karena pandemi memaksa lahirnya kebijakan baru sebagai upaya penanganan dan pengendalian penyakit yang di mana masyarakat tidak dapat langsung mengaplikasikannya dalam kehidupan seharihari.

Berdasarkan www.cnbcindonesia.com, COVID-19 dinyatakan sebagai pandemi pada hari Rabu tanggal 11 Maret 2020. World Health Organization (WHO) mengumumkan hal tersebut saat angka kasus mencapai 126.063 orang. Pandemi sendiri berarti skala penyebaran penyakit terjadi secara global di seluruh dunia. Hal ini karena selain di negara asal virus ini, penyebaran penyakit sudah menyebar ke seluruh dunia termasuk Indonesia.

Saat COVID-19 dinyatakan sebagai pandemi, di Indonesia sendiri telah terjadi 27 kasus. Tidak lama dari dinyatakannya COVID19 sebagai pandemi, Indonesia menerapkan kebijakan Social Distancing. Konsep Social Distancing merupakan anjuran untuk melakukan upaya mengurangi atau memutus rantai penyebaran COVID-19. Hal yang dapat dilakukan dalam penerapan social distancing ini adalah menjaga jarak dengan manusia lainnya dengan jarak minimal 2 meter dan tidak bersentuhan atau melakukan kontak langsung dengan orang lain serta menghindari kerumunan (Buana, 2020).

Kebijakan baru ini berdampak pada semua aspek kehidupan khususnya aspek ekonomi di mana pandemi menyebabkan naiknya angka pengangguran, keterbatasan bahan pangan dan penurunan daya beli masyarakat. Selain itu, pandemi Covid-19 juga menyebabkan terbatasnya akses terhadap sistem sumber karena semua sektor kehidupan lebih mengutamakan kasus-kasus darurat saja sebagai prioritas pelayanan. Adapun dalam aspek kesehatan, banyaknya tenaga medis yang menjadi korban, kurangnya alat pelindung diri dan banyak fasilitas kesehatan yang tidak beroperasi karena pemberlakuan pembatasan. Sedangkan dalam aspek pendidikan, aktivitas belajar mengajar dialihkan menjadi pengajaran berbasis online di mana hal ini juga perlu penyesuaian dalam pelaksanaannya. Selain itu, masih banyak lagi dampak yang ditiimbulkan dari pandemi Covid-19 dalam aspek kehidupan lainnya.

Uraian permasalahan di atas membuktikan bahwa pandemi membuat 
semakin banyaknya kelompok rentan, khususnya pelayanan sosial karena pandemi ini sudah menjadi masalah sosial. Termasuk ke dalam kelompok yang membutuhkan pelayanan sosial ini adalah para ABH (Anak Berhadapan dengan Hukum) dan remaja marjinal yang sedang mendapatkan pendidikan di LPKA. Para ABH ini kemudian disebut dengan Andik atau Anak Didik karena mereka merupakan anak yang sedang dididik dan dibina di LPKA (Lestari \& Santoso, 2019)

Jika saat situasi normal saja masih banyak faktor penghambat terlaksananya pelayanan sosial, maka tentu saja di tengah pandemi ini faktor penghambat dalam pelaksanaan pelayanan sosial semakin banyak lagi. Hal ini karena banyaknya kelompok rentan tidak sebanding dengan banyaknya upaya yang dapat dilakukan oleh penyedia layanan. Hal ini tentu saja disebabkan oleh pembatasan aktivitas sosial di mana setiap individu wajib menerapkan physical distancing sehingga lembaga pelayanan sosial sulit untuk melaksanakan pelayanan secara langsung. Oleh karena itu, hal ini membutuhkan pemecahan terkait bagaimana cara agar pelayanan dapat tetap dilakukan di tengah pandemi.

\section{METODE}

Penelitian ini dilaksanakan di Kota Bandung, Jawa Barat dengan subjek penelitian Mitra Citra Remaja (MCR) yang merupakan Youth Center yang menjadi bagian dalam pelayanan sosial di Perkumpulan Keluarga Berencana Indonesia (PKBI). Jenis penelitian yang dilakukan adalah penelitian tindakan atau Action Research yang dilakukan melalui pengkajian suatu permasalahan atau fenomena dalam ruang lingkup yang terbatas. Dalam hal ini yaitu MCR melalui refleksi diri dalam melakukan kegiatan penggalangan dana dan kampanye sosial. Pengkajian ini dilakukan dalam konteks pengorganisasian (organizing) berbagai elemen yang ada di dalam satu struktur kerelawanan dalam rangka penggalangan dana dan kampanye sosial.

\section{PEMBAHASAN}

\section{Struktur Kerelawanan}

Perkumpulan Keluarga Berencana Indonesia atau PKBI adalah sebuah Lembaga Swadaya Masyarakat (LSM) yang mempelopori gerakan Keluarga Berencana (KB) di Indonesia. PKBI berpusat di Jakarta dan memiliki cabang di setiap provinsi di Indonesia termasuk Jawa Barat.

PKBI Jawa Barat menjalankan berbagai program kemasyarakatan yang berlandaskan pada strategi utama yaitu mengembangkan pelayanan kesehatan reproduksi komprehensif dan terpadu, mengembangkan pusat informasi, edukasi dan konseling berbasis hak dan perspektif gender serta meningkatkan kemampuan organisasi melalui pengembangan Sumber Daya Manusia (SDM), sumber dana dan jaringan kerjasama (https://pkbijabar.or.id). Ada beberapa kegiatan yang dilakukan oleh PKBI diantaranya yakni, kegiatan bersama remaja, ODHA, dan kegiatan pelayanan kesehatan reproduksi kepada masyarakat.

PKBI Jawa Barat memiliki Youth Center yang bernama Mitra Citra Remaja (MCR). MCR berfokus pada pemberian informasi, edukasi, dan layanan konsultasi bagi remaja kota Bandung. MCR memiliki visi "Mewujudkan terbentuknya remaja yang sehat dan bertanggung jawab”. Sedangkan misi MCR yaitu menjadi satu lembaga yang berpartisipasi dalam pemberian layanan informasi, edukasi dan konseling bagi remaja (khususnya masalah kesehatan reproduksi), Pemberian informasi, edukasi atau pelatihan, dan konseling yang berorientasi masa depan, Peduli dengan berbagai permasalahan remaja yang ditunjukkan melalui aksi (layanan informasi, edukasi, dan konseling) dan rekomendasi, Pengembangan riset akan kesehatan reproduksi remaja, Memberikan layanan pada seluruh remaja tanpa membeda-bedakan kalangan, ras, kelompok, dll), Pengembangan lembaga untuk dapat menjadi pusat kegiatan remaja, dan Pengembangan kemitraan dengan berbagai lembaga yang memiliki kepedulian terhadap permasalahan remaja. 
Dalam masa pandemi, MCR melakukan perekrutan relawan dalam rangka penggalangan dana dan kampanye sosial.
Adapun struktur kerelawanan yang terbentuk adalah sebagai berikut:

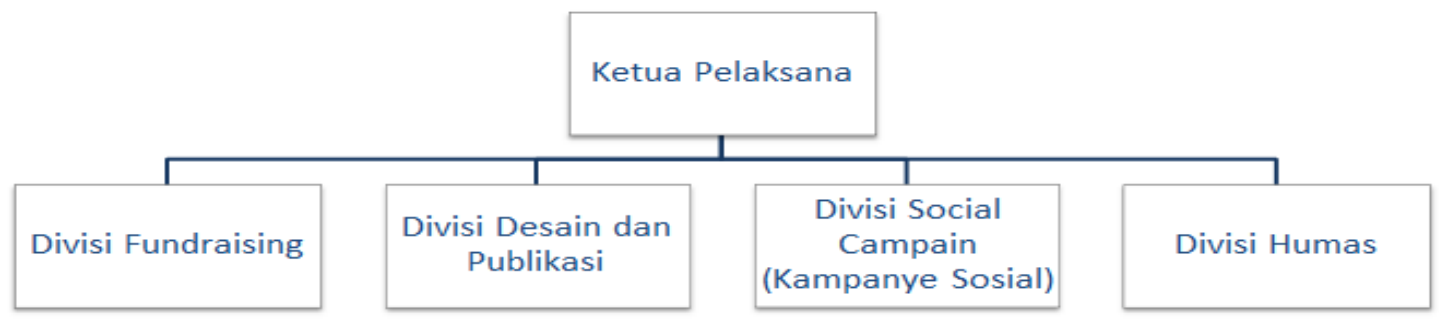

Gambar 1 Struktur Kerelawanan Lembaga, 2020

Struktur tersebut memiliki peran-peran tersendiri dalam upaya mencapai tujuan kerelawanan yaitu menggalang dana sekaligus meningkatkan kesadaran masyarakat mengenai isu kesehatan baik kesehatan secara umum maupun kesehatan reproduksi.

\section{Tujuan Kegiatan Penggalangan Dana dan Kampanye Sosial}

Kegiatan penggalangan dana dan kampanye sosial ini merupakan bentuk realisasi MCR dalam menjalankan misinya. Salah satunya yaitu peduli dengan berbagai permasalahan remaja yang ditunjukkan melalui aksi (layanan informasi, edukasi, dan konseling). Dalam hal ini MCR melakukan penggalangan dana untuk mendonasikan paket personal hygiene kepada andik-andik di LPKA dan remaja marjinal yang merupakan bagian dari penerima manfaat program-program di PKBI.

Andik-andik di LPKA dan remaja marjinal menjadi sasaran pemberian manfaat karena selama masa pandemi andik-andik di LPKA mengalami keterbatasan akses terhadap alat-alat kebersihan diri. Hal ini karena selama pandemi LPKA tidak menerima besuk dari keluarga sehingga andik-andik di LPKA tidak memiliki alat-alat kebersihan diri karena alatalat tersebut tidak tersedia di LPKA itu sendiri. Selain itu, remaja marjinal dalam hal ini adalah remaja dengan HIV/AIDS. Dengan demikian, MCR melakukan kegiatan penggalangan dana dan kampanye sosial agar masyarakat memiliki kepedulian dan kesadaran terhadap isu-isu kesehatan dan reproduksi di tengah pandemi khususnya bagi populasi rentan seperti andikandik LPKA dan remaja marjinal.

\section{Susunan Kegiatan Penggalangan Dana dan Kampanye Sosial}

Melakukan

kegiatan-kegiatan

kerelawanan di tengah pandemi merupakan hal yang tidak mudah. Selain tidak dapat melakukan interaksi secara langsung dengan penerima manfaat, kegiatan utama dari penggalangan dana dan kampanye sosial pun hanya dapat dilakukan secara daring. Platform yang digunakan sebagai media penyampaian pesan-pesan kampanye dan penggalangan dana adalah aplikasi Instagram. Hal ini karena saat ini Instagram merupakan salah satu platform yang mudah diakses oleh berbagai kalangan (Susanti, Gunawan, \& Sukaesih, 2019). Selain itu, Instagram memiliki fitur yang interaktif khususnya bagi remaja sehingga diharapkan Instagram dapat menjadi media yang efektif dalam keberlangsungan kegiatan. Adapun susunan kegiatan penggalangan dana dan kampanye sosial ini adalah sebagai berikut:

Tabel 1 Kegiatan Penggalangan Dana dan Kampanye Sosial Tahun 2020

\begin{tabular}{|l|l|}
\hline APRIL & \multicolumn{1}{|c|}{ KEGIATAN } \\
\hline Senin, 20/04 & Donasi (Kitabisa \& Manual) \\
\hline Rabu, 22/04 & $\begin{array}{l}\text { Siapa \& Apa itu MCR? } \\
\text { (Desain/Video) }\end{array}$ \\
\hline Sabtu, 25/04 & Bingo Covid 2.0 \\
\hline Senin, 27/04 & $\begin{array}{l}\text { Update Donasi (Kitabisa \& } \\
\text { Manual) }\end{array}$ \\
\hline MEI & \multicolumn{2}{|c|}{} \\
\hline Jum'at, 1/05 & Question: MCR itu apa? \\
\hline Rabu, 6/05 & Instastory interaktif (this/that) \\
\hline
\end{tabular}




\begin{tabular}{|l|l|}
\hline Jum'at, 8/05 & Perkenalan Konten Live IG \\
\hline Sabtu, 9/05 & $\begin{array}{l}\text { Live! Diskusi: Perubahan } \\
\text { Hormon dan Menstruasi }\end{array}$ \\
\hline Sabtu, 16/05 & Update Donasi \\
\hline Rabu, 18/05 & Penyaluran Donasi \\
\hline
\end{tabular}

\section{Proses Pengorganisasian (Organizing)}

Manajemen dan organisasi merupakan hal yang tak terpisahkan. Hal ini karena organisasi tidak dapat digerakan tanpa manajemen dan manajemen tidak dapat diimplementasikan tanpa organisasi. Terdapat beberapa unsur dalam manajemen yakni, unsur organisasi, adanya tujuan dan sasaran, ada usaha dari orang-orang yang terlibat dalam organisasi dan menggunakan sistem dan prosedur dalam pelaksanaannya (Rifa'i \& Fadhli, 2013). Hal ini juga berlaku bagi organisasi pelayanan sosial. Organisasi pelayanan sosial memerlukan sistem manajerial karena pelayanan tidak dapat dilakukan jika hanya mengandalkan niat baik. Lebih dari itu, pelayanan sosial memerlukan sistem manajerial yang baik dalam melakukan pelayanan.

Menurut Kettner (2002), terdapat lima aspek penting yang saling terintegrasi dalam manajemen lembaga palayanan sosial yaitu aspek planning, organizing, human resources, finance/fundraising dan information system. Kelima aspek tersebut merupakan sistem manajerial agar organisasi pelayanan sosial dapat menjadi usaha yang terstruktur dan efisien. Selain itu, diperlukan kemampuan dan keahlian yang dimiliki oleh manusia yang ada dalam sebuah organisasi pelayanan sosial. Hal ini karena kemampuan dan keahlian sumber daya manusia dalam sebuah organisasi pelayanan sosial dapat menunjang efektivitas pelayanan sosial yang diberikan. Mengenai sumber daya manusia dalam organisasi pelayanan sosial, setidaknya terdapat tiga komponen yakni dewan direksi (board management), staf pelaksana dan relawan (volunteer) (Raharjo, 2002). Ketiga komponen tersebut bekerja sama dalam memanfaatkan sumber-sumber yang ada dalam upaya pelayanan.

Adapun yang disebut pengorganisasian adalah usaha penciptaan hubungan tugas yang jelas antar personalia, sehingga dengan demikian setiap orang dapat bekerja bersamasama dalam kondisi yang baik untuk mencapai tujuan-tujuan organisasi (Rifa'i \& Fadhli, 2013). Dalam hal ini, pengorganisasian yang dilakukan dalam penggalangan dana dan kampanye sosial disini adalah penetapan struktur, pembagian tugas dan wewenang, serta penetapan mekanisme kerja antar divisi agar terjadi harmonisasi dalam pelaksanaannya.

Kegiatan yang dilakukan dalam kerelawanan ini meliputi penggalangan dana dan kampanye sosial. Kedua kegiatan ini dilaksanakan karena adanya potensi dalam melakukan crowdfunding di Indonesia mengingat tingginya filantropis masyarakat (Adiansah, Mulyana, \& Fedryansyah, 2016). Jadi, apabila sebuah organisasi membutuhkan dana dalam menjalankan suatu kegiatan, kini crowdfunding dapat menjadi salah satu pilihan untuk menggalang dana secara mandiri selain tergantung pada donatur. Dalam hal ini, kegiatan kerelawanan menyertakan kegiatan kampanye sosial dalam penggalangan dana agar selain dana terkumpul juga kesadaran masyarakat menjadi terbangun khususnya terkait isu-isu kesehatan diri dan kesehatan reproduksi.

Kegiatan relawan pada kelembagaan Mitra Citra Remaja (MCR) PKBI Jawa Barat dalam situasi pandemi COVID-19 tentunya menyesuaikan dengan kondisi, baik dalam koordinasi kegiatan maupun menjalankan kegiatan kerelawanan. Untuk tahap persiapan dan perencanaan kegiatan dilakukan melalui media sosial yakni aplikasi WhatsApp serta media meeting online melalui Google Meet, sedangkan pelaksanaan kegiatan diinformasikan melalui instagram resmi MCRPKBI Jabar, serta Instagram relawan dan social campaigner.

Berbagai kegiatan kerelawanan dalam situasi pandemi COVID-19 diantaranya; Memberikan informasi seputar COVID-19 
kepada masyarakat dengan sumber data WHO (World Health Organization), meliputi informasi dasar virus corona, gejala-gejala yang terjadi, media \& cara penyebaran, serta pencegahan yang bisa dilakukan. Kegiatan lainnya yaitu mengadakan kuis menarik melalui Instagram stories resmi MCR dengan mengangkat tema kesehatan reproduksi. Seiring dengan berjalannya kegiatan, mulai dari 20 April 2020 MCR-PKBI Jabar berinisiatif bersama relawan yang tergabung untuk menggalang dana dengan tujuan membantu ABH (Anak Berhadapan dengan Hukum) dan remaja marjinal di wilayah dampingan PKBI jabar, dimana mereka merupakan kelompok rentan yang seharusnya mendapatkan perhatian serius namun terabaikan pada masa pandemi COVID-19.

Seperti yang kita ketahui berdasarkan anjuran pemerintah, pandemi COVID-19 menuntut kita untuk selalu menjaga pola hidup bersih dan sehat. Bantuan yang diberikan berupa paket personal hygiene yang berperan penting dalam kesehatan kelompok rentan dan dapat menghindari adanya gangguan pada fungsi alat reproduksi. Untuk remaja marginal wilayah dampingan PKBI JABAR, dan ABH di LPKA Bandung, paket bantuan terdiri dari; handuk, sabun cair, sampo, odol, sikat gigi, masker, hand sanitizer, pembalut, dan vitamin C. Sedangkan paket untuk ABH di LPKA Bandung kurang lebih sama, namun tanpa pembalut.

Kemudian, pada 9 Mei 2020 diadakan sesi live Instagram dan tanya jawab online melalui Instagram dengan tema "Pengaruh Perubahan Hormon pada Perempuan dan Lakilaki dalam Kehidupan Sehari-hari”. Dalam sesi live Instagram tersebut, dilakukan dengan suasana santai yang cocok bagi remaja. Sesi live Instagram bersama pakar yang sekaligus menjadi Pembicara utama, yaitu dr. Sandra Suryadana dari @perempuanberkisah yang juga merupakan founder dari @doktertanpastigma. Tujuan dari sesi live Instagram tersebut yaitu untuk berbagi ilmu serta mengisi waktu dalam mendukung kampanye \#dirumahaja dengan berkegiatan positif.
Setelah sesi live Instagram, relawan melakukan penyaluran donasi kepada andikandik di LPKA dan remaja marjinal di Kota Bandung pada tanggal 18 Mei 2020. Penyaluran donasi dilakukan oleh perwakilan relawan bersama pihak PKBI yang berdomisili di Bandung. Hal ini karena mayoritas relawan yang tergabung berdomisili di luar bandung sedangkan saat itu sedang berlaku kebijakan PSBB (Pembatasan Sosial Berskala Besar). Hal ini tidak memungkinkan bagi relawan yang berdomisili di luar Bandung untuk ikut menyalurkan donasi secara langsung. Setelah penyaluran donasi, kegiatan kerelawanan pun berakhir.

Menjadi relawan dalam situasi pandemi merupakan suatu kebanggan. Selain dapat belajar berempati kepada masyarakat rentan, menjadi relawan juga merupakan satu langkah nyata dalam mewujudkan nilai kemanusiaan. Bagaimana penulis dapat melihat realita kelompok-kelompok rentan dan merancang aksi nyata sebagai upaya pertolongan. Berbagai dinamika dalam upaya memberikan pertolongan kepada kelompok rentan di tengah situasi pandemi harus direncanakan dengan baik dan matang. Hal ini terutama pada kegiatan penggalangan dana dan kampanye sosial.

Beberapa hambatan baik eksternal maupun internal yang dialami dalam pelaksaan kegiatan penggalangan dana dan kampanye sosial. Adapun hambatan internal dalam kegiatan penggalangan dana dan kampanye sosial adalah sulitnya berkoordinasi antar divisi. Hal ini karena pertemuan-pertemuan rapat hanya dapat dilakukan melalui konferensi telepon yang sering kali terjadi kesalahan komunikasi. Selain itu, sulitnya menentukan waktu untuk pertemuan karena seringkali ada hambatan jaringan. Sedangkan hambatan eksternal dalam kegiatan penggalangan dana dan kampanye sosial yaitu jangkauan akun Instagram yang digunakan sebagai media membagikan informasi penggalangan dana belum terlalu luas, maraknya penggalangan dana di berbagai platform menjadikan lambatnya progres penggalangan dana. Selain itu, karena kontak personal disebarkan secara 
luas hal ini menjadikan rentannya penipuan yang mengatasnamakan donatur.

Selain hambatan, pelayanan sosial secara tidak langsung pun menyuguhkan beberapa keuntungan yakni penggunaan platform penggalangan dana dinilai lebih efektif dalam penggalangan dana dan kampanye sosial yang dilakukan melalui Instagram pun memperoleh timbal balik positif dari beberapa pihak yang memiliki ketertarikan pada isu-isu kesehatan reproduksi. Kampanye sosial menjadi metode penyediaan layanan yang mudah dijangkau oleh remaja yang memiliki keraguan untuk pergi ke profesional. Dengan demikian, beberapa hambatan dan keuntungan dalam pelaksanaan kerelawanan ini memberikan kesan dan menjadi pengalaman yang sangat berharga mengenai bagaimana cara melakukan penggalangan dana yang efektif dan bagaimana cara melakukan kampanye sosial agar dapat menjangkau berbagai elemen dalam masyarakat.

\section{KESIMPULAN DAN REKOMENDASI}

\section{Kesimpulan}

Pandemi merupakan situasi baru yang melahirkan kebijakan baru pula. Hal ini mengharuskan adanya berbagai perubahan dan penyesuaian agar kehidupan dapat terus berjalan termasuk organisasi pelayanan sosial. Meskipun dalam situasi pandemi, pelayanan harus tetap dilakukan mengingat situasi pandemi berdampak buruk pada kelompokkelompok rentan seperti andik-andik di LPKA dan remaja-remaja marjinal yang tidak dapat memenuhi kebutuhan dan tidak dapat mengakses sistem sumber selama pandemi. Pelayanan tidak dapat dilakukan secara langsung karena adanya kebijakan social distancing, jadi organisasi-organisasi sosial harus memikirkan cara lain dalam memberikan pelayanan salah satunya penggalangan dana melalui platform daring dan kampanye sosial. Pelayanan yang dilakukan secara daring memiliki beberapa hambatan yang berasal dari internal organisasi dan eksternal organisasi khususnya dalam proses pengorganisasian. Hal ini dikarenakan berbagai faktor salah satunya komunikasi yang tidak dapat dilakukan secara langsung. Komunikasi ini menjadikan koordinasi tidak dapat berjalan lancar sehingga pencapaian tujuan tidak dapat dilakukan secara maksimal. Akan tetapi, melakukan kegiatan pelayanan tidak langsung menggunakan metode penggalangan dana dan kampanye sosial di tengah pandemi merupakan pengalaman baru yang sangat berharga khususnya bagi relawan. Hal ini karena relawan harus berpikir lebih dalam menentukan upaya-upaya yang dilakukan agar efektif dan efisien.

\section{Rekomendasi}

Berdasarkan kesimpulan di atas, penulis merekomendasikan beberapa hal yang dapat dilakukan dalam upaya pemberian layanan selama pandemi, yakni:

1) Sebelum melakukan sebuah program, alangkah baiknya untuk melakukan penelitian terkait fenomena di lapangan.

2) Merancang rencana dengan matang dan melibatkan seluruh komponen yang akan berkegiatan.

3) Membuat kontak terpadu dalam semua kegiatan.

4) Mengoptimalkan media masa menjadi media arus utama pelaksanaan program layanan.

\section{DAFTAR PUSTAKA}

Adiansah, W., Mulyana, N., \& Fedryansyah, M. (2016). Potensi Crowdfunding Di Indonesia Dalam Praktik Pekerjaan Sosial. Prosiding Penelitian Dan Pengabdian Kepada Masyarakat, 3(2). https://doi.org/10.24198/jppm.v3i2.13655 Buana, D. R. (2020). Analisis Perilaku Masyarakat Indonesia dalam Menghadapi Pandemi Virus Corona (Covid-19) dan Kiat Menjaga Kesejahteraan Jiwa. SALAM: Jurnal Sosial Dan Budaya Syar$I, 7(3)$.

https://doi.org/10.15408/sjsbs.v7i3.15082

Lestari, M. A., \& Santoso, M. B. (2019).

Pelaksanaan Assertiveness Training Pada Anak Berhadapan dengan Hukum (ABH) di LPKA Bandung. Jurnal Kumawula: Jurnal Pengabdian Kepada Masyarakat, 2(2), 104-116. https://doi.org/http://10.24198/kumawula. vli3.23566 
Nathan, A. J., \& Scobell, A. (2012). How China sees America. Foreign Affairs, 91(5), 1689-1699.

https://doi.org/10.1017/CBO9781107415

324.004

Raharjo, S. T. (2002). Manajemen Relawan Pada Organisasi Pelayanan Sosial. Sosiohumaniora, 4(3), 150-173.

Susanti, S., Gunawan, W., \& Sukaesih. (2019). Pengembangan Pemasaran Bordir dan Kelom Geulis Tasikmalaya Melalui Media Sosial. Jurnal Kumawula: Jurnal Pengabdian Kepada Masyarakat, 2(3), 248-261.

https://doi.org/http://10.24198/kumawula. vli3.25256

Tangdilintin, P. (2015). Mengenal Masalah Sosial. 1-49. 